\title{
THE CHIEF OBJECT OF HIGH-SCHOOL CHEMISTRY.
}

\author{
By O. L. Brauer, \\ Selma, California.
}

Various reasons are given for teaching chemistry in the high school. Among these are: To prepare for college; to discipline the mind; to teach the scientific method; to teach the student to be more observing of nature; to give him a better understanding of natural phenomena; and to impart more or less useful information. All these are well and good, but it seems to me the greatest thing to be accomplished by high-school chemistry has been overlooked; that is, to show the great dependence of all national and industrial advancement and all industries upon science and scientific research, and the great necessity of supporting chemical research and its applications in every possible way.

Statistics show that, on the average, about one in ten of the graduates of the high schools go to college, and many of these do not take any more chemistry. Hence it is obvious that the preparation for college should only be incidental to the main object of the course. If you examine those persons who had only preparatory chemistry about ten years ago, you find that they remember little more than that water is $\mathrm{H}_{2} \mathrm{O}$ and sulphuric acid is $\mathrm{H}_{2} \mathrm{SO}_{4}$. The imparting of useful information, then, can only be a small part of the purpose of the course, since so little of it is retained. The other secondary objects of the chemical course are of unquestionable value, yet nevertheless secondary, to the main purpose.

The need of chemical enlightenment can best be expressed by a quotation from an address by Arthur D. Little, Massachusetts Institute of Technology, published in the January (1916) number of the Journal for Industrial and Engineering Chemistry:

"There is a great need at the present time on the part of bankers, capitalists, men of affairs, and directors of industry, and in no less clegree on the part of superintendents, foremen, work people, and the public generally, for a better appreciation of the part which science plays in furthering industrial development, increasing the efficiency of production, raising the scale of wages, and insuring preparedness, whether for peace or war.

"This need arises from the fact that men of affairs, and especially financiers, have seldom received a scientific training or acquired a working knowledge of the scientific method or fully understood the scientific point of view. They consequently often 
fail to realize the intrinsic merit of industrial propositions which are based essentially upon new applications of applied science, and to gauge with accuracy their chances of success.

"They can, it is true, employ specialists, as in fact they should do in any case, but they often cannot weigh the validity of expert reports, because of ignorance of the scientific method and suspicion of the value of its deductions. As a result of these too common limitations in financial circles, the development of large and ultimately highly profitable industrial undertakings is often postponed for years.

"The directors of industry - though happily with many notable exceptions, especially among those to whom have been entrusted the affairs of our largest corporations-frequently ignore science. Willfully or unconsciously, they cut themselves off from that great accumulation of coordinated knowledge and organized common sense which has been painfully built up by thousands of the best minds in every land during the last hundred years.

"Proposals based on the scientific study of a problem or situation are, therefore, often rejected by these gentlemen as "theoretical" because the man who prides himself on being "practical" either cannot absorb the data or does not dare to trust himself to the conclusions. Thus antiquated methods persist, avoidable wastes continue, and dividends decline.

"The attitude of superintendents and foremen and of the industrial workers generally to the innovations and betterments proposed by science is far too commonly one of militant skepticism or hostile suspicion."

American Industry has grabbed for large and quick returns from the exploitation of our natural resources. The time is about past when a man, by a clever turn, can appropriate to himself the vast resources of the country and amass a colossal fortune without contributing proportionally to the wealth of the nation. Many of the American industries have been characterized by profligate waste. The time has arrived when "Conservation" is the slogan, and profits must come as much from the utilization of the by-products as from the old-line business. This will require scientific research and applied science more and more. Business is learning and must learn much faster that knowledge and science are valuable and must be paid for. President McLauren, of Massachusetts Institute of Technology, says if one tenth of the scientific knowledge now in textbooks were rightly applied fortunes would be made every year. 
Germany has learned to pay for science and research, and all the world has been paying her homage industrially. American minds are just as bright as those of the Germans. We could have anything if we would pay for it. The German industries have been profitable. Industries that were planned to yield fifteen per cent profits years ago have developed under the investigators until before the war they were paying thirty per cent profit. C. F. Chandler, in a recent address, pointed with considerable amusement to the announcement which New York newspapers made with great pride that a factory for synthetic dyes was to be built on Long Island on a $40 \times 70$-ft. lot. They heralded this as something extraordinary. Prof. Chandler contrasted this with F. Bayer \& Company's plant in Germany, covering a square mile of ground, which ten years ago employed 300 chemists and 8,000 workmen-a company with over fifty-three years' experience at making synthetic dyes.

The recent proposal of a five million dollar research or testing laboratory for the U. S. Navy is opposed by many as an extravagance. Baekaland, of the Naval Consulting Board, points out that it is far better to make the mistakes in the laboratory at the cost of a few thousand dollars than in the Navy at a cost of millions. He points out that two million dollars is lost annually by corrosion in condenser tubes in our warships. If one million in research could prevent this, which it no doubt could, a million would be saved. This is just one small illustration of the many similar problems confronting the Navy.

The past history of American enterprise shows many largescale failures that might easily have been averted by a few' thousand dollars spent in scientific investigation. An illustration that came to my notice is from a plant for making grape juice at Lodi, California. At this place a plant was erected at an expense of about $\$ 200,000$. The company fell through and the plant stopped because they couldn't clarify the juice. A good research chemist in a year's time could have settled that question one way or the ether and prevented the loss. In fact, professors at the University of California have recently perfected methods that they believe would have clarified that very juice. In spite of thousands of similar examples over the United States, there are scores of Ph. D.'s that can scarcely find suitable employment at $\$ 100$ per month; men who are almost geniuses and capable of firstclass research.

The universities are longing to plunge in and help on all these 
problems, but because of lack of funds and opportunity they can only help in a meager way. Men of the highest ability and training, with $\mathrm{Ph}$. D. degrees, are asked to teach in our universities at salaries from $\$ 900$ to $\$ 1,200$ per year. This condition is shameful. It is an insult to the teaching profession; it is a shameful lack of appreciation of what science and scientifically-trained men could do for the country. We pretend by our patent laws to encourage inventions and discoveries. I have in mind men scientifically trained who have roughly outlined very important inventions, but because of the pressing necessity of making a living and supporting a family must lay these away. Capitalists are very skeptical, as yet, of the possibilities of research. A thing must be a demonstrated certainty before they will touch it, and then they are scarcely willing to pay its lowest worth. To perfect an invention or a process sometimes takes years of undivided attention. It is only the person in unusual circumstances who can do this.

Such are the conditions. How are the bankers, the capitalists, the men of affairs, the directors of industry, the superintendents, foremen, the working people and the thinking public going to be taught the value of scientific knowledge and the necessity of paying for it? The most direct way, it seems to me, is through the high schools. The bankers, capitalists, etc., of tomorrow are in the scinools of today. If the high-school science gave its students a real understanding of the part science could and should play in our country, the task would be mostly done. Why do students take science if not to learn what science means and what it has to offer? Why is it put in the schools? Do the patrons of the schools care anything about the allotropic forms of arsenic or the oxides of chlorine? What they want to know is if it be wise to establish national research laboratories; to endow scientific schools; or whether it be wise to invest in such or such an enterprise; or can such and' such a thing be accomplished; whom can we get to accomplish it; and why has Germany led the world in so many industries.

The greatest thing high-school science should accomplish is to show the student the great significance of science, the field of any particular science and what its knowledge means and can hope to do. In chemistry let us drop all irrelevant and purposeless descriptive parts and substitute the real spirit and enthusiasm of chemistry in its place. 